\title{
STRATEGI PEMASARAN BUAH SEMANGKA BULAT NON BIJI TERHADAP PENDAPATAN PETANI DI DESA TRIYOSO KECAMATAN BELITANG KABUPATEN OKU TIMUR
}

\author{
(Aminullah)
}

\begin{abstract}
The purpose of this research were to : (1) To know the income of non-seedled watermelon farm in Triyoso Village, Belitang Sub-district, OKU Timur Regency, (2) To know the marketing strategy of non-seed watermelon farming in Triyoso Village Belitang District, OKU Timur Regency through descriptive analysis of SWOT. This research was conducted in Triyoso Village, Belitang District, East OKU Regency. The location of the study was determined purposively (Purposive) with the consideration that this area is a potential watermelon producer and plays an important role for the availability of watermelons in Triyoso and Belitang District. The research has been conducted in march 2014 to complete. The study found that the average non-grade A grade seed yield was 13,819, the class B average production was 2,210 kg / production process, and the $C$ class was $558 \mathrm{~kg}$ with the total production amount of 16,587 and the average yield of the non- The average production cost of $R p$ 17,502,344 / production process obtained an average non-kernel round watermelon income of $R p$ 43,035,720 / production process and Strategy that can be developed in Marketing of non-seed round watermelon fruit in Triyoso Village Belitang District are: Maintaining the quality of seed products and enhancing cooperation with stakeholders and strengthening partnerships to maintain continuity of production and can survive in the market, monitoring the marketing risk of watermelon fruit with the government, Improving the management of watermelon farming Round non seed through cooperation With relevant agencies in order to increase competitiveness in the marketing of watermelon fruit.
\end{abstract}

Key Words : Melon Fruit Marketing Strategy, Melon Fruit Cultivation, Income.

\section{PENDAHULUAN}

\section{A. Latar Belakang}

Potensi subsektor perikanan Indonesia sangat besar dikarenakan sektor perikanan merupakan salah satu sumber mata pencaharian bagi sebagian masyarakat Indonesia. Besarnya potensi yang dimiliki subsektor perikanan di Indonesia menyebabkan produksi perikanan Indonesia selalu mengalami peningkatan yang cukup signifikan dari tahun ke tahun. Menurut Kementerian Kelautan dan Perikanan RI, produksi perikanan Indonesia tahun 2010 mencapai 10,83 juta ton atau mengalami kenaikan sebesar 10,29 persen dibandingkan dengan tahun 2009 sebesar 9,82 juta ton. Bahkan pada tahun 2014 pemerintah menargetkan produksi perikanan Indonesia mencapai 22,39 juta ton (DKP 2010).

Semangka merupakan tanaman buah berupa herba yang berasal dari daerah kering tropis dan subtropis Afrika, kemudian berkembang dengan pesat ke berbagai Negara seperti Afrika Selatan, Cina, Jepang, dan Indonesia. Di Indonesia varietas yang cocok dibudidayakan dibagi menjadi dua kelompok yaitu, semangka lokal dan semangka hibrida. Batang semangka bulat dan lunak, berbulu sedikit berkayu, batangnya merambat, panjangnya antara 3,5 meter, cabang-cabang lateral mirip cabang utama, daunnya berbentuk caping, bertangkai panjang dan bentuknya bersebrangan, bunga semangka berjenis kelamin satu berwarna kuning berdiameter sekitar $2 \mathrm{~cm}$. Buah semangka memiliki kandungan air yang tinggi sekitar $92 \%$ dan menjadikan semangka pembersih tubuh yang sangat baik dan kaya akan kalium dan kalsium. Warna merah pada buah semangka menandakan tingginya kadar likopen, salah satu komponen kerotenoid seperti halnya betakaroten. Dibandingkan antioksidan lainnya, seperti vitamin $\mathrm{C}$ dan $\mathrm{E}$, kekuatan likopen dalam memerangi radikal bebas jauh lebih ampuh (Moch Baga Kalie: 1993).

Di Indonesia, usaha produksi benih semangka secara komersial sampai saat ini belum ada. Benih semangka masih dihasilkan sendiri oleh para petani. Benih ini dipanen dari pertanaman hasil penyerbukan massal di alam terbuka, dipilih tanaman yang menghasilkan buah yang baik. Apabila cara demikian dilakukan secara terus-menerus, maka kemurnian mutu benih tidak terjamin lagi.

Indonesia merupakan salah satu negara penghasil buah tropis yang memiliki keanekaragaman dan keunggulan cita rasa yang cukup baik bila dibandingkan dengan buah- 
buahan dari negara-negara penghasil buah tropis lainnya. Produksi buah tropika nusantara terus mengalami peningkatan dari tahun ke tahun. Pada Tabel 1.1 dapat dilihat tingkat kebutuhan buahbuah dan produksi buah-buahan, dan terlihat kebutuhan akan buah-buahan pada tahun 2009 meningkat sebesar $27,22 \%$ apabila dibandingkan dengan tahun 2005 sedangkan, produksinya hanya meningkat sebesar $20,57 \%$.

Tabel 1. Tingkat kebutuhan dan produksi Buahbuahan di Indonesia lima Tahun Terakhir (2005 - 2009).

\begin{tabular}{lcc}
\hline Tahun & Kebutuhan (ton) & Produksi (ton) \\
\hline 2005 & 14.267 .891 & 14.786 .599 \\
2006 & 15.153 .063 & 15.193 .297 \\
2007 & 16.093 .149 & 15.838 .000 \\
2008 & 17.091 .554 & 16.946 .000 \\
2009 & 18.151 .902 & 17.829 .000 \\
\hline
\end{tabular}

Sumber: Direktorat Jendral Hortikultura (dikutip Kusmahayadi, 2010).

Meningkatnya produksi budidaya buah semangka terutama di Kabupaten OKU Timur, juga meningkatkan permintaan akan buah semangka sehingga membuka peluang usaha yang lebih besar bagi pelaku usahatani buah semangka terutama semangka non biji. Meningkatnya permintaan buah semangka juga akan meningkatkan permintaan produksi semagka sebagai input untuk kegiatan usahatani. Peningkatan tersebut memberikan dampak positif yaitu terbentuknya peluang pasar yang lebih luas dengan harga yang cukup bersaing.

Ditinjau dari aspek pemasaran terutama pertimbangan pemasaran buah semangka di Desa Triyoso, memilih wilayah sekitar Kabupaten OKU Timur sebagai sentra pemasaran buah semangka terutama Kecamatan Belitang. Berikut adalah tabel produksi buah semangka di Kabupaten OKU Timur Kecamatan Belitang dari tahun 2009-2011.

Tabel 2. Produksi Semangka di Kecamatan

\begin{tabular}{llrrr}
\multicolumn{5}{c}{ Belitang Tahun $2009-2011}$. \\
\hline No & Desa & Jumlah produksi semangka per tahun (ton) \\
2009 & 2010 & 2011 \\
\hline 1 & Trivoso & 3,5 & 5,7 & 7,2 \\
2 & Tawang Rejo & 2,8 & 2,9 & 3,3 \\
3 & Banjar Rejo & - & 1,3 & 1,6 \\
4 & Gunung Mas & 2,7 & - & 4 \\
5 & Karang Kemiri & 2,8 & - & - \\
6 & Banyu Mas & - & 5 & - \\
\hline \multicolumn{1}{r}{ Jumlah } & 11,8 & 14,9 & 16,1
\end{tabular}

Sumber:Ketahanan Pangan Holtikultura Kecamatan Belitang OKU Timur 20092011.
Untuk kawasan Belitang minat konsumen untuk mengkonsumsi buah semangka sangatlah tinggi sehingga memicu permintaan pasar yang sangat tinggi.Desa Triyoso Kecamatan Belitang Kabupaten OKU Timur mempunyai peluang untuk mengembangkan usahatani buah semangka.

\section{B. Rumusan Masalah}

1. Berapa besar pendapatan petani dari usahatani buah semangka non biji di Desa Triyoso Kecamatan Belitang Kabupaten OKU Timur.

2. Bagaimana strategi pemasaran dari usahatani buah semangka non biji di Desa Triyoso Kecamatan Belitang Kabupaten OKU Timur ditinjau dari kajian analisis SWOT.

\section{Tujuan dan Kegunaan}

1. Mengetahui pendapatan pada usahatani buah semangka non biji di Desa Triyoso Kecamatan Belitang Kabupaten OKU Timur.

2. Mengetahui strategi pemasaran usahatani buah semangka non biji di Desa Triyoso Kecamatan Belitang Kabupaten OKU Timur melalui analisis deskriptif SWOT.

\section{Model Pendekatan}

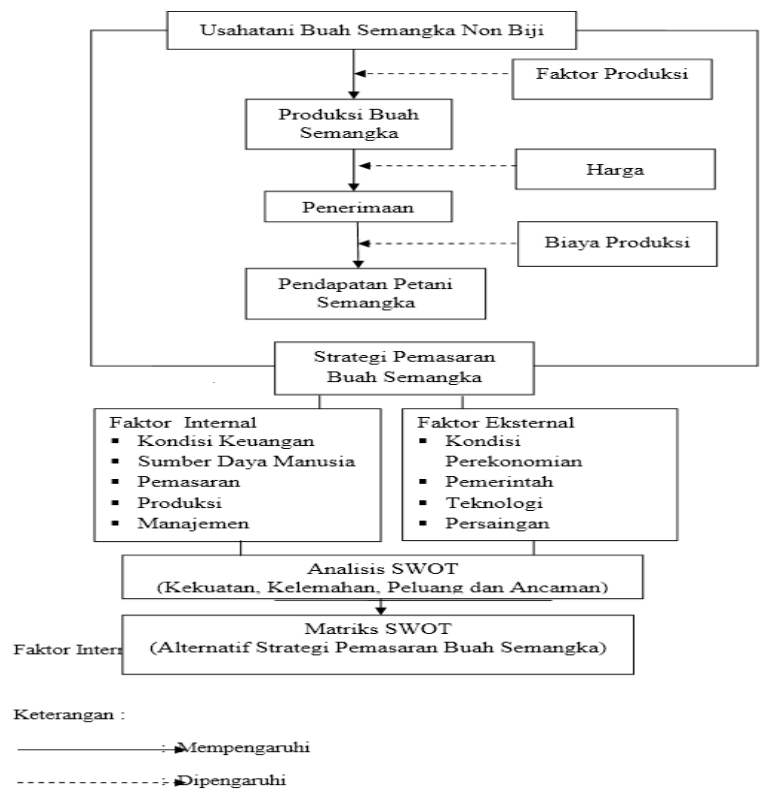

Gambar 1. Model pendekatan penelitian secara diagramatik.

\section{METODOLOGI PENELITIAN}

\section{A. Tempat dan Waktu}

Penelitian ini telah dilaksanakan di Desa Triyoso Kecamatan Belitang Kabupaten OKU Timur. Lokasi penelitian ditentukan secara sengaja (Purposive) dengan pertimbangan bahwa 
daerah ini merupakan penghasil semangka yang sangat berpotensi dan berperan penting bagi ketersediaan semangka yang ada di Triyoso dan Kecamatan Belitang. Penelitian telah dilaksanakan pada Bulan Maret 2014 sampai dengan selesai.

\section{B. Metode Penelitian}

Metode penelitian yang digunakan adalah metode survei, yaitu penelitian untuk memperoleh fakta dan keterangan tentang sesuatu yang ingin diteliti, baik dengan sensus maupun dengan sample. Metode survei adalah penyelidikan yang diadakan untuk memperoleh fakta-fakta dari gejala-gejala yang ada dan mencari keteranganketerangan secara faktual. Metode ini digunakan untuk mengetahui berapa besar biaya pada usahatani semangka bulat non biji yang digunakan petani berdasarkan data yang didapatkan dari petani sampel.

\section{Metode Penarikan Contoh}

Metode penarikan contoh dilakukan secara sengaja (purposive sampling) terhadap petani buah semangka bulat non biji yang usahanya telah lebih satu tahun di Desa Triyoso Kecamatan Belitang Kabupaten OKU Timur tersebut terdapat 14 petani semangka bulat non biji yang ada di Desa Triyoso, sehingga petani mengambil sampel dari 14 populasi yang ada di Desa Triyoso kecamatan Belitang Kabupaten OKU Timur.

\section{Metode Pengolahan Data}

Data yang diperoleh diolah secara tabulasi dan dianalisis dengan menggunakan rumus matematis serta dijelaskan secara deskriptif kuantitatif, yaitu dengan memaparkan hasil yang didapat dalam bentuk uraian yang sistematik.

1. Untuk mengetahui besarnya biaya produksi, penerimaan, pendapatan di Kabupaten OKU Timur. Menggunakan rumus :
a. $\mathrm{TC}=\mathrm{FC}+\mathrm{VC}$ (Yudi, 2010)
b. $\mathrm{TR}=\mathrm{Y} \times \mathrm{P}$. (Yudi, 2010)
c. $\mathrm{I}=\mathrm{TR}-\mathrm{TC}$ (Yudi, 2010)
d. $\mathrm{R} / \mathrm{C}$ ratio $=\frac{T R}{T C}$

Keterangan :

$\mathrm{TC}=$ Total Cost/Biaya Total (Rp/proses)

$\mathrm{FC}=$ Fixed Cost/Biaya Tetap (Rp/proses)

$\mathrm{VC}=$ Variable Cost/Biaya Variabel (Rp/proses)

$\mathrm{TR}=$ Total Revenue $/$ Total Penerimaan $(\mathrm{Rp})$

$\mathrm{P}=$ Price $/$ Harga $(\mathrm{Rp})$

$\mathrm{Y}=$ Yeild/Hasil Produksi (Rp)

$\mathrm{I}=$ Income/Pendapatan $(\mathrm{Rp})$
$\mathrm{TR}=$ Total Revenue/Total Penerimaan $/(\mathrm{Rp})$

$\mathrm{TC}=$ Total Cost/Total Biaya (Rp)

Kaidah :

$\mathrm{R} / \mathrm{C}>1$ Maka usaha tersebut menguntungkan

$\mathrm{R} / \mathrm{C}=1$ Impas

$\mathrm{R} / \mathrm{C}<1$ Maka usaha tersebut tidak menguntungkan / Rugi.

2. Analisis Deskriptif Kualitatif

Analisis deskriptif kualitatif digunakan untuk mengidentifikasi faktor internal dan eksternal yang menjadi kekuatan, kelemahan, peluang dan ancaman dalam sistem agribisnis pemasaran buah semangka non biji di Desa Triyoso.

3. Matrik SWOT

Analisis SWOT digunakan untuk mengidentifikasi dan menganalisis faktor-faktor strategis sistem agribisnis buah semangka non biji baik secara internal (kekuatan, kelemahan) maupun eksternal (peluang, ancaman) dalam kondisi saat ini kemudian berusaha membandingkan antara faktor internal kekuatan kelemahan dengan faktor eksternal peluang ancaman. Lingkungan internal yang dianalisis meliputi kondisi keuangan, sumber daya manusia, pemasaran, prouksi/operasional, dan manajemen. Sedangkan lingkungan eksternal yang dianalisis meliputi kondisi perekonomian, sosial budaya, pemerintah, teknologi dan persaingan.

Untuk merumuskan alternatif strategi pengembangan pemasaran buah semangka non biji di Kabupaten OKU Timur. Digunakan analisis Matriks SWOT. Matrik SWOT dapat menggambarkan secara jelas bagaimana peluang dan ancaman eksternal yang dihadapi suatu usaha sehingga dapat disesuaikan dengan kekuatan dan kelemahan yang dimilikinya. Matrik ini dapat menghasilkan empat sel kemungkinan alternatif strategi, yaitu strategi S-O, strategi W-O, strategi W-T, dan strategi S-T.

Terdapat 8 tahapan dalam membentuk matrik SWOT :

1. Menentukan faktor-faktor peluang eksternal agribisnis pemasaran buah semangka non biji di Desa Triyoso.

2. Menentukan faktor-faktor ancaman eksternal agribisnis pemasaran buah semangka non biji di Desa Triyoso.

3. Menentukan faktor-faktor kekuatan internal agribisnis pemasaran buah semangka non biji di Desa Triyoso.

4. Menentukan faktor-faktor kelemahan internal agribisnis pemasaran buah semangka non biji di Desa Triyoso. 
5. Menyesuaikan kekuatan internal dengan peluang eksternal untuk mendapatkan strategi S-O.

6. Menyesuaikan kelemahan internal dengan peluang eksternal untuk mendapatkan strategi W-O.

7. Menyesuaikan kekuatan internal dengan ancaman eksternal untuk mendapatkan strategi S-T.

8. Menyesuaikan kekuatan internal dengan ancaman eksternal untuk mendapatkan strategi W-T.

\section{HASIL DAN PEMBAHASAN}

\section{A. Biaya Produksi Usahatani Semangka Bulat Non Biji}

Biaya produksi (total cost) merupakan akumulasi biaya - biaya yang yang terdiri dari biaya tetap dan variabel. Biaya tetap (fixed cost) merupakan biaya yang tidak habis per proses produksi, meliputi biaya sewa lahan dan penyusatan alat. Rincian biaya tetap disajikan pada tabel berikut ini.

Tabel 3. Rata-rata Biaya Tetap Usahatani Semangka Bulat Non Biji di Desa Triyoso Kecamatan Belitang OKU Timur .

\begin{tabular}{clr}
\hline No. & \multicolumn{1}{c}{ Rincian Biaya Tetap } & $\begin{array}{c}\text { Biaya Tetap } \\
\text { (Rp Proses) }\end{array}$ \\
\hline 1. & Biaya Sewa Lahan & 1.873 .810 \\
2. & Rincian Biaya Penyusutan Alat & \\
& - Cangkul & 23.859 \\
- Handsprayer & 33.466 \\
- Sabit & 5.513 \\
- Gunting & 10.714 \\
- Ember & 25.786 \\
- Lori & 24.478 \\
- Batu Asahan & 7.214 \\
- Mesin Sedot Air & 215.551 \\
- Selanng Drip & 78.700 \\
- Selanng Pokok & 44.699 \\
- Paralon & 6.169 \\
- Gayung & 11.107 \\
Total Biaya Penyusutan & 487.254 \\
Total BiayaTetap & 2.361 .064 \\
\hline
\end{tabular}

Sumber: Hasil Olahan Data Primer 2014.

Berdasarkan tabel di atas rata-rata biaya tetap usahatani semangka bulat non biji di Desa Triyoso dalam satu kali proses produksi adalah Rp. 2.361.064 yang terdiri dari biaya rata-rata sewa lahan dengan rata-rata luas lahan 0,56 ha $\mathrm{Rp}$ 1.873.810 dan rata-rata biaya penyusutan alat $\mathrm{Rp}$ 487.254 dari penggunaan cangkul sampai dengan penggunaan gayung.
Penggunaan biaya variabel (variable cost) yang merupakan biaya yang dapat habis dalam per proses produksi yang meliputi biaya sarana produksi dan biaya tenaga kerja pada budidaya semangka bulat non biji di Desa Triyoso Kecamatan Belitang adalah sebagai berikut :

Tabel 4. Rata-rata Biaya Sarana Produksi Usahatani Semangka Bulat Non Biji di Desa Triyoso Kec. Belitang OKU Timur.

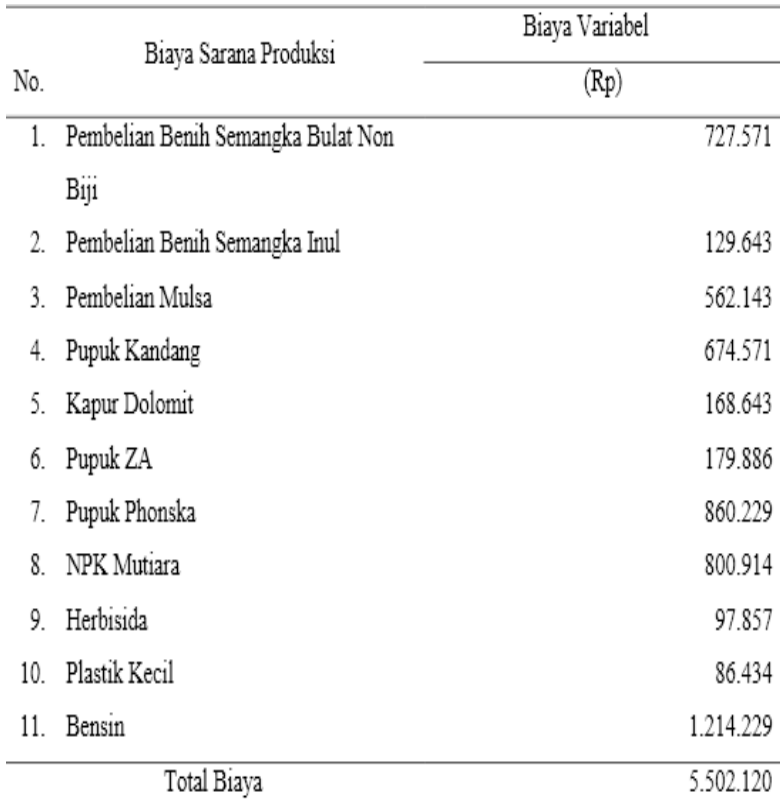

Sumber : Hasil Olahan Data Primer 2014.

Berdasarkan tabel di atas rata-rata biaya sarana produksi usahatani semangka bulat non biji di Desa Triyoso sebesar Rp 5.502.120 yang terdiri dari biaya pembelian benih semangka sampai dengan penggunaan bensin. Selain itu biaya tenaga kerja yang dikeluarkan oleh petani semangka bulat non biji Rincian biaya tenaga kerja dalam usahatani tersebut dapat dilihat dalam tabel berikut ini.

Tabel 5. Biaya Tenaga Kerja Usahatani Semangka Bulat Non Biji di Desa Triyoso Kecamatan Belitang OKU Timur.

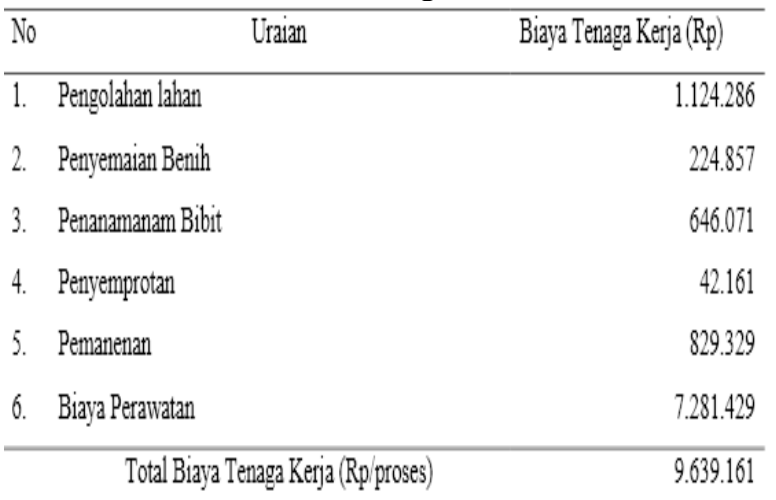

Sumber : Hasil Olahan Data Primer 2014. 
Berdasarkan uraian yang pada Tabel di ketahui bahwa penggunaan biaya tenaga kerja pada usahatani semangka bulat non biji di Desa Triyoso Kecamatan Belitang dari biaya pengolahan lahan, penyemaian benih, penanaman bibit, penyemprotan, dan pemanenan dalam satu kali proses produksi memerlukan biaya rata-rata sebesar Rp 9.639.161.

Tabel 6. Rincian Biaya Produksi Usahatani Semangka Bulat Non Biji (Rp/ha/proses) di Desa Triyoso Kecamatan Belitang Kabupaten OKU Timur .

\begin{tabular}{|c|c|c|}
\hline \multirow{2}{*}{ No. } & \multirow{2}{*}{ Uraian } & Biaya Produksi \\
\hline & & (Rp) \\
\hline & Biaya Tetap (A) & 2.361 .064 \\
\hline 2. & - Biaya Pentyusutuan Alat & 487.254 \\
\hline 3. & - Biaya Sevwa Lahant & 1.873 .810 \\
\hline 4. & Biaya Variabel (B) & 15.546 .120 \\
\hline 5. & - Biaya Sarana Produksi & 5.502 .120 \\
\hline 6. & - Biaya Tenagga Kerja & 9.639 .161 \\
\hline 7. & Total Biaya Produksi $(A-B)$ & 17.502 .344 \\
\hline
\end{tabular}

Sumber : Hasil Olahan Data Primer 2014.

Berdasarkan tabel di atas dalam lampiran 35 total rata-rata biaya produksi semangka bulat non biji dalam satu kali proses produksi di Desa Triyoso Kecamatan Belitang dengan luas lahan 0,56 ha memerlukan biaya produksi sebesar $\mathrm{Rp}$ 17.502.344 yang terdiri dari biaya sewa lahan, biaya penyusutan alat, biaya sarana produksi, dan biaya tenaga kerja.

\section{B. Produksi,Penerimaan, Pendapatan, dan R/C Ratio Usahatani Semangka Bulat Non Biji.}

Penerimaan merupakan pendapatan kotor dari usahatani semangka bulat non biji yang berasal dari hasil kali antara jumlah produksi/panen dengan harga jual semangka. Sedangkan pendapatan merupakan selisih antara jumlah penerimaan dengan biaya produksi dalam usahatani semangka bulat non biji di Desa Triyoso Kecamatan Belitang. Rata - rata penerimaan usahatani semangka bulat non biji sebesar Rp 60.538.064 per proses produksi, Berikut hasil produksi semangka bulat non biji di Desa Triyoso Kecamatan Belitang.
Tabel 7. Rata-rata Penerimaan Usahatani Semangka Bulat Non Biji (Rp/ha/proses) di Kecamatan Belitang Mulya Kabupaten OKU Timur .

\begin{tabular}{|c|c|c|}
\hline No. & Uraian & $\begin{array}{l}\text { Nilai Usahatani Semangka } \\
\text { (Rp/Proses Produksi) }\end{array}$ \\
\hline \multicolumn{3}{|c|}{ 1. Produksi $(\mathrm{Kg})$} \\
\hline & Kelas A & 13.819 \\
\hline & Kelas B & 2.210 \\
\hline & Kelas C & 558 \\
\hline & Total Produksi & 16.587 \\
\hline \multirow[t]{4}{*}{2.} & Harga (Rp) & \\
\hline & Kelas A & 3700 \\
\hline & Kelas B & 3500 \\
\hline & Kelas C & 3000 \\
\hline \multirow[t]{5}{*}{3.} & Penerimaan (Rp) & \\
\hline & Kelas A & 51.130 .564 \\
\hline & Kelas B & 7.735 .000 \\
\hline & Kelas C & 1.672 .500 \\
\hline & Total Penerimaan (A) & 60.538 .064 \\
\hline 4. & Biaya Produksi (B) & 17.502 .344 \\
\hline 5. & Pendapatan (A-B) & 43.035 .720 \\
\hline 6. & R/C Ratio & 3,5 \\
\hline
\end{tabular}

Sumber : Hasil Olahan Data Primer 2014.

Hasil produksi usahatani semangka bulat non biji di Desa Triyoso dijual berdasarkan kelas yang berbeda karena dalam pemanenan semangka bulat non biji dilakukan tidak secara bersamaan dan hasil produksi dan bentuk semangka yang berbeda sehingga dalam pemanenan dibedakan menjadi tiga kelas yaitu kelas A, kelas B, dan Kelas C, sehingga mempunyai nilai jual (harga) yang bervariasi. Semanka bulat non biji kelas A dipasarkan dengan harga $\mathrm{Rp} 3.700 / \mathrm{Kg}$, kelas B dengan harga $\mathrm{Rp} 3.500 / \mathrm{Kg}$, dan kelas $\mathrm{C}$ dijual dengan harga $\mathrm{Rp} 3.000 / \mathrm{Kg}$.

Rata-rata hasil produksi semangka bulat non biji kelas A adalah $13.819 \mathrm{~kg} /$ proses produksi dengan harga jual $\mathrm{Rp} 3.700 / \mathrm{kg}$ sehingga memberikan penerimaan sebesar $\mathrm{Rp}$ 51.130.564/proses produksi. Semangka bulat non biji kelas B rata-rata produksinya adalah 2.210 $\mathrm{kg} /$ proses produksi dengan harga jual $\mathrm{Rp} 3.500 / \mathrm{kg}$ sehingga penerimaan yang diperoleh sebesar $\mathrm{Rp}$ 7.735.000/proses produksi. Rata-rata produksi semangka kelas $\mathrm{C}$ adalah sebanyak $558 \mathrm{~kg}$ dengan harga jual $\mathrm{Rp}$ 3000/kg dan memproleh penerimaan sebesar $\mathrm{Rp}$ 1.672.500/proses produksi.

Pendapatan usahatani semangka bulat non biji di Desa Triyoso Kecamatan Belitang merupakan pendapatan bersih petani responden 
dengan luas lahan 0,56 ha dari hasil penerimaan rata-rata sebesar $\mathrm{Rp}$ 60.538.064/proses produksi dikurang dengan rata-rata biaya produksi yang digunakan sebesar Rp 17.502.344/proses produksi memperoleh rata-rata pendapatan usahatani semangka bulat non biji sebesar Rp 43.035 .720 /proses produksi.

Analisis R/C Ratio merupakan tingkat perbandingan atau rasio antara penerimaan dan biaya produksi. Analisis R/C Ratio adalah suatu analisis yang digunakan untuk mengetahui tentang untung atau rugi dari suatu usaha dengan membandingkan antara total penerimaan dengan total biaya produksi (Firdaus, 2009). R/C Ratio pada usahatani semangka bulat non biji di Desa Triyoso Kecamatan Belitang diperoleh nilai 3,5. $\mathrm{Hal}$ ini menunjukkan usaha tersebut menguntungkan, karena dari Rp 1 biaya produksi yang dikeluarkan, maka diperoleh penerimaan 3,5.

\section{Analisis Faktor Internal dan Faktor Eksternal}

Analisis faktor internal dan eksternal dilakukan dengan meninjau faktor-faktor di luar dan di dalam agribisnis strategi pemasaran semangka bulat non biji di Desa Triyoso Kecamatan Belitang Kabupaten OKU Timur. Analisis faktor internal dapat digunakan untuk mengetahui seberapa besar kekuatan dan kelemahan buah semangka non biji dalam pemasaran saat ini serta pengaruhnya terhadap daya saing buah semangka daerah lain.

\section{Faktor Internal}

\section{a. Faktor Kekuatan (Strength)}

1. Harga Buah Semangka Non Biji Murah

Harga buah semangka non biji terkait dengan daya beli masyarakat juga sebagai daya saing dengan buah semangka luar Desa Triyoso, masyarakat menilai harga buah semangka non biji hasil budidaya petani jauh lebih murah dibandingkan dengan buah semangka di daerah lain seperti dari Kecamatan Semendawai Suku III, Buay Madang Timur dan Sekitarnya.

\section{Buah Semangka Non Biji Tersedia}

Ketersediaan buah semangka non biji untuk memenuhi kebutuhan dinyatakan meningkat sepanjang tahun. Akan tetapi yang perlu untuk diperhatikan adalah efisiensi produksi belum dapat meningkatkan daya saing pasar.

$$
\begin{aligned}
& \text { 3. Produksi Buah Semangka Non Biji } \\
& \frac{\text { Memenuhi Kebutuhan }}{\text { Pengembangan produksi hartikultura }} \\
& \text { terutama untuk komoditi buah semangka } \\
& \text { mempunyai dampak yang sangat berarti terhadap }
\end{aligned}
$$

pertumbuhan ekonomi Desa Triyoso. Produksi buah semangka bulat non biji mampu memenuhi kebutuhan masyarakat sejalan dengan meningkatnya permintaan dari konsumen Desa Triyoso maupun luar daerah desa Triyoso.

4. Kemudahan Mendapatkan Buah Semangka Bulat Non Biji

Buah semangka bulat non biji mudah untuk didapatkan, hampir di semua pasar tradisional besar dan kecil, kios buah selalu ada. Namun kadangkala memang terdapat jenis buah semangka lain seperti semangka inul, semangka biji yang tidak dapat ditemui karena sifat buah banyak petani tidak membudidayakan buah semangka jenis tersebut..

5. Teknologi Informasi Mendukung PemasaranSemangka di Desa Triyoso

Keberhasilan pembangunan pertanian antara lain di tentukan oleh kemampuan sumber daya manusia dalam mengelola sistem pertanian yang sesuai dengan perkembangan ilmu pengetahuan dan teknologi (iptek). Menurut Dimyati (2007), yang mengungkapkan bahwa upaya-upaya dalam pembentukan jaringan pasar bermutu yaitu salah satunya dapat ditempuh melalui bantuan teknologi informasi semisal layanan melalui website, radio, televisi, koran atau aneka bentuk layanan cetak yang lain. Pemasaran buah semangka non biji di Desa Triyoso biasanya dipasarkan oleh pedagang besar di Desa Triyoso di pasar-pasar tradisonal terdekat dan sekitar wilayah Desa Triyoso.

6. Kemitraan Petani Buah Seamangka denga Pengusaha dalam Hal Pemasaran

Adanya perubahan lingkungan strategis berupa liberalisasi perdagangan, otonomi daerah, perubahan preferensi konsumen, serta kelestarian lingkungan, menuntut suatu perubahan cara beroperasinya kelembagaan kemitraan usaha agribisnis hortikultura. Dalam penelitian ini dapat diinformasikan bahwa kemitraan petani buah dengan pengusaha terhadap pemasaran buah lokal baik. Seperti dalam kajian Saptana $d k k$ (2006) yang menjelaskan pola kemitraan rantai pasok melalui Pola Kelompok Tani terdapat beberapa keuntungan yang diperoleh karena bergabung dengan Assosiasi padagang buah semangka dan melakukan kemitraan usaha antara lain adalah:

a) Harga buah semangka stabil sehingga harga tidak dipermainkan pedagang,

b) Adanya jaminan pemasaran,

c) Mendapatkan informasi teknologi baru tentang pembudidayaan buah semangka. 
d) Tidak akan terjadi booming akibat pengaturan luas tanam, waktu tanam dan varietas yang diminta pasar.

e) Adanya apresiasi terhadap komoditas semangka dengan trade mark daerah sentra produksi tertentu.

\section{b. Faktor Kelemahan (Weakness)}

1. Teknik Budidaya buah semangka oleh petani masih sederhana Di Desa Triyoso telah berkembang sentra-sentra produksi buah-buahan, tetapi pengelolaannya masih belum optimal sehingga produktivitasnya rendah. Kebun semangka dikelola dengan teknologi yang minimal.

2. Kualitas produksi buah semangka non biji dinilai masih kurang petani produsen buah dinilai oleh masyarakat belum dapat memenuhi selera atau preferensi konsumen buah semangka pada umumnya, misal dalam hal rasa buah, konsumen umumnya menganggap rasanya kurang manis. Walaupun ditopang dengan produksi yang melimpah tetapi kualitas rasa buah semangka belum dapat mencerminkan daya saing terhadap buah semangka varietas lain.

3. Kualitas tampilan dan ukuran buah semangka non biji kurang seragam buah semagka di Desa Triyoso jika dilihat dari segi keseragaman kualitas tampilan dan ukuran buah sedikit jauh berbeda dengan produk buah semangka daerah lain yang masuk kepasaran untuk daerah Belitang. Kepala Pusat Kajian Buah-buahan Tropika Institut Pertanian Bogor Yayah K Wagiono mengatakan, rendahnya kualitas dan produktivitas buah lokal (semangka) akibat luasan lahan yang sempit dan penanaman buah masih dikerjakan sebagai usaha sampingan sehingga menyebabkan keseragaman produk yang tidak terjamin (Kompas, 2002). Produk buahsemangka non biji Desa Triyoso yang ada jika ditinjau dari mutu visual masih kurang.

4. Frekuensi promosi buah semangka kurang konsisten.

5. Promosi yang menyangkut performance buah semangka non biji dianggap masih jarang dilakukan baik oleh pemerintah maupun pihak swasta yang terkait dengan komoditi hortikultura sehingga perlu diadakan sebuah evaluasi. Masyarakat yang terpilih menjadi responden semuanya mengakui belum ada frekuensi promosi buah semangka non biji Desa Triyoso hanya kadang-kadang dilakukan dan sebagian menjawab tidak pernah dilakukan sama sekali.

6. Promosi buah semangka hasil usaha budidaya Desa Triyoso promosi pemasaran buah semangka bulat non biji yang telah dilakukan dan masih terus diupayakan masih kurang memenuhi sasaran, dari kalangan akademisi yang dijadikan sebagai responden pada umumnya menjelaskan bahwasanya faktor promosi belum mendukung sepenuhnya terhadap pengembangan agribisnis buah semangka bulat non biji di Desa Triyoso Kecamatan Belitang.

7. Kualitas pengemasan buah semangka bulat non biji kurang bagus, kualitas pengemasan buah bukan hanya di Desa Triyoso tetapi juga secara nasional masih kurang bagus dibanding buah impor. Menurut Buntaran dalam Trubus (2007:68), tingkat kerusakan buah di Indonesia dapat mencapai sekitar $35-40 \%$ yang bisa dihitung sejak dari pekebun panen sampai ketangan konsumen dengan penyebab yaitu tata niaga perbuahan yang terlalu panjang. Disetiap tingkatan tata niaga pengemasannya berbeda-beda seperti keranjang, plastik, Styrofoam dan kardus, karena buah sering berganti-ganti wadah, benturan lebih sering terjadi pada akhirnya buah menjadi lebih rentan rusak. Pemasaran buah semangka non biji di Desa Triyoso belum menggunakan pengemasan yang baik, hanya menggunakan jerami sebagai pelindung keruasakan buah semangka setelah proses pemanenan saat pendistribusian buah semangka kepada konsumen.

8. Harga buah lain pengganti semangka seperti pepaya dan jeruk, dengan adanya harga buah lain dibanding buah semangka merupakan kelemahan bagi pemasaran buah semangka dan kekuatan buah semangka sehingga produsen buah harus menyikapi peluang pasar ini agar dapat bersaing dengan produk buah lain. Bagaimanapun, konsumen akan mempertimbangkan faktor harga dalam menentukan barang apa yang dibelinya.

9. Petani sangat memerlukan pembinaan atau penyuluhan dari para penyuluh pertanian agar para petani mengetahui budidaya pengembangan semangka dan aplikasi praktiknya selain itu dapat memasarkan semangka dengan hasil yang tidak selalu 
merugikan sehingga dapat meningkatkan pendapatan petani.

\section{Analisis Faktor Eksternal}

Faktor eksternal merupakan pengaruh dari luar pada pemasaran buah semangka non biji di desa Triyoso Kecamatan Belitang Kabupaten OKU Timur.

\section{a) Faktor Peluang (Opportunities)}

1) Buah lokal disukai konsumen buah lokal merupakan prioritas konsumen Desa Triyoso membeli buah semangka produksi luar daerah baik kesegaran maupun harganya.

2) Tempat membeli buah semangka di pasar tradisional, untuk membeli buah-buahan, konsumen buah di Desa Triyoso menetapkan pilihan di pasar tradisional. Kualitas Pengemasan Terhadap Pembelian Buah Lokal Berpengaruh Secara umum kualitas pengemasan berpengaruh terhadap pembelian buah lokal. Menurut Supriyanto dalam Trubus (2007:69), menjelaskan bahwa kemasan buah menjadi kunci dunia perbuahan tidak hanya di Desa Triyoso bahkan nasional sehingga tidak sekedar mengurangi tingkat kerusakan tetapi mendongkrak nilai jual.

3) Infrastruktur penunjang distribusi buah semangka. Pembangunan infrastruktur boleh jadi merupakan salah satu agenda penting dan bertujuan untuk mempermudah akses bagi produsen maupun konsumen atau pedagang perantara kepada atau meningkatkan efisiensi pemasaran. Sehubungan dengan hal tersebut Pemerintah di Kabupaten OKU Timur tengah melakukan berbagai langkah strategis yang diharapkan akan menjadi daya tarik bagi petani budidaya buah semangka dengan membentuk asosiasi pedagang buah semangka untuk memudahkan pemasaran buah semangka.

4) Kesadaran masyarakat dalam hal pola hidup sehat semakin meningkat antara lain ditandai dengan kesadaran dalam mengkonsumsi makanan yang sehat diantaranya adalah mengkonsumsi buah semangka yang tidak hanya didasarkan atas kesukaan tetapi juga lebih cenderung dipengaruhi oleh kesadaran akan pentingnya mutu gizi yang dikonsumsi setiap harinya.

1. Buah semangka di Desa Triyoso tidak hanya dipasarkan di pasar tradisional saja, tetapi juga telah terbukti berhasil menembus pasar moderen misalnya supermarket. Hal ini membuktikan bahwa buah lokal memiliki keunggulan yaitu pangsa pasar yang luas, realitas ini menggambarkan kondisi masyarakat banyak yang menyukai, daya beli masyarakat mampu untuk membeli dan yang terpenting adalah bisa dirasakan oleh semua lapisan masyarakat.

2. Dunia pendidikan termasuk salah satu elemen penting dalam proses pengembangan agribisnis buah semangka di Desa Triyoso. Pendidikan dunia pendidikan dalam hal ini antara lain adalah dalam bentuk pendidikan kesadaran mengkonsumsi buah dan mencintai produksi dalam negeri dan bagi Perguruan tinggi diharapkan dalam hal penelitian dan penerapan iptek bagi pengembangan buah semagka di Desa Triyoso. Peranan Perguruan tinggi dengan penelitian dan pengembangan yang dilakukan, beserta pemerintah dituntut untuk berperan aktif, seperti halnya pengembangan mekanisasi pertanian demi prospek pengembangan agribisnis buah lokal Jawa Timur (Hermawan, 2006).

3. Pengaruh keberadaan para tengkulak/ pedagang pengumpul maupun pengecer terhadap pemasaran buah semangka menguntungkan. Meskipun rantai pemasaran komoditi buah semangka sangat panjang dan kemungkinan harga yang diterima oleh petani rendah, disisi lain keberadaan para tengkulak atau pedagang pengumpul maupun pengecer dirasakan sangat menguntungkan petani dari aspek pemasaran.

4. Pengaruh meningkatnya jumlah penduduk terhadap permintaan buah semangka bulat non biji tinggi. Prospek pengembangan komoditas hortikultura di masa mendatang cukup menggembirakan karena permintaan yang cenderung meningkat dengan meningkatnya jumlah penduduk yang saling berkaitan dengan kesadaran untuk mengkonsumsi buah-buahan.

5. Petani semangka dapat bekerja sama dengan pemerintah, salah satunya melalui PIR (Perusahaan Inti Rakyat) yang dapat memperpendek mata rantai pemasaran sehingga pendapatan petani lebih tinggi. Dalam sistem PIR ini, petani bertindak sebagai plasma, perusahaan inti bertanggung jawab membeli semua produksi yang dihasilkan oleh petani plasma dengan perjanjian kerja sama antara petani dan perusahaan inti. 
b) Faktor Ancaman (Threats)

1) Promosi melalui media massa terhadap permintaan buah semangka bulat non biji kurang berpengaruh. Berbagai macam kiat untuk mengembangkan agribisnis buah dapat melalui media massa. Akan tetapi, responden menilai peran media massa selama ini kurang berpengaruh dan mungkin sangat tidak berpengaruh.

2) Meningkatnya Supermarket dan Hypermarket terhadap permintaan buah lokal rendah Menurut Laporan World Bank (2007), perdagangan eceran modern dan pasar swalayan sedang marak di Indonesia, bertumbuh sebanyak 20 persen per tahun sejak dicabutnya pembatasan pada tahun 1998. Namun, konsumen menentukan pasar-pasar tradisional untuk membeli buah-buah lokal atau dengan kata lain berkembangnya pasar-pasar swalayan tidak mempengaruhi permintaan buah semangka di Desa Triyoso.

3) Pengaruh harga faktor produksi terhadap permintaan buahsemangka bulat non biji rendah. Penyedian sarana produksi sangat penting untuk kontinuitas produk buah lain. Menariknya, dari informasi yang didapatkan dari responden kenaikan faktor harga produksi saat ini tidak terlalu berpengaruh terhadap permintaan buah semangka.

4) Pengaruh masuknya buah lain terhadap permintaan buah semangka rendah dari hasil penelitian dapat diketahui pengaruh masuknya buah impor terhadap permintaan buah lokal (semangka) rendah. Senada dengan hal tersebut Saragih dalam Kompas (2007), menyatakan banyaknya buah-buahan impor yang memasuki pasar dalam negeri masih normal dan hingga sekarang peredaran buah impor belum mengganggu atau membahayakan eksistensi buah lokal secara signifikan.

5) Peran serta lembaga perbankan terhadap agribisnis buah lokal (semangka) rendah. Peran sektor pertanian yang sangat strategis dalam perekonomian belum diimbangi dengan dukungan penyediaan modal yang memadai. Lembaga perbankan formal yang ada saat ini cenderung bias dan lebih mengutamakan pembiayaan non pertanian. Kelangkaan kredit perrtanian dapat berpengaruh terhadap produktivitas dan pendapatan petani terutama bagi petani gurem. Kajian Saptana et. al. (2001) menemukan bahwa pada usaha komoditas hortikultura tingkat suku bunga pinjaman dapat mencapai 3055 persen pertahun dengan peminat peminjam kredit ini cukup besar mengingat prosedur peminjaman yang sederhana, pencairan dana cepat dan tanpa agunan.

6) Kebijakan pemerintah (misalnya; pembebasan impor buah) terhadap agribisnis buah lokal (semangka) negatif Pemerintah dengan segala kewenangan (authority) memegang kontrol terhadap komoditi buah dalam negeri. Dengan kebijakan menetapkan bea masuk buah impor sebesar 5\% dengan tujuan melindungi petani justru memiliki pengaruh negatif karena kelimpahan produksi buah harus bersaing dengan stock buah impor.

7) Peranan asosiasi produsen atau pemasar buah terhadap agribisnis buah semangka kurang baik. Kondisi agribisnis buah semangka saat ini yang masih jauh dari harapan, dapat dilihat dari lemahnya peran aktif asosiasi produsen atau pemasar buah semangka dalam perkembangannya.

\section{Perumusan Alternatif Strategi Pengembangan Agribisnis Pemasaran Semangka Bulat Non Biji.}

Untuk merumuskan alternatif strategi yang diperlukan dalam mengembangkan usahatani Semangka Bulat Non Biji di Desa Triyoso Kecamatan Belitang analisis Matriks SWOT. Matriks SWOT menggambarkan secara jelas bagaimana peluang dan ancaman eksternal dapat dipadukan dengan kekuatan dan kelemahan internal sehingga dihasilkan rumusan strategi pengembangan agribisnis usahatani semangka bulat non biji. Matriks ini menghasilkan empat sel kemungkinan alternatif strategi, yaitu strategi S-O, strategi W-O, strategi W-T, dan strategi S-T. Setelah mengidentifikasi faktor-faktor internal dan eksternal yang menjadi kekuatan dan kelemahan serta peluang dan ancaman dalam mengembangkan agribisnis semangka bulat non biji di Desa Triyoso Kecamatan Belitang, maka diperoleh beberapa alternatif strategi yang dapat dipertimbangkan, antara lain: 
Tabel 8. Analisa Matrik SWOT Strategi Pemasaran Buah Semangka Bulat Non Biji.

\begin{tabular}{|c|c|c|}
\hline Ekstemal & $\begin{array}{l}\text { STRENGTHS (S) } \\
\text { 1. Harga buah semangka bulat non } \\
\text { biji murah } \\
\text { 2. Rasa buah semangka bulat non } \\
\text { biji enak } \\
\text { 3. Tampilan buah semangka bulat } \\
\text { non biji menark untuk dilihat } \\
\text { 4. Buah semangka bulat non biji } \\
\text { 5. Produksi buah semangka bulat } \\
\text { 5on biji memenuhi }\end{array}$ & \begin{tabular}{|l} 
WEAKNESS (W) \\
1. Teknik budidaya buah semangka \\
bulat non biji oleh petani \\
sedarhana \\
2. Kemampuan petani memproduksi \\
buah semangka bulat non biji \\
yang diminati kongumen kurang \\
ahli \\
3. Kualitas buah semangka bulat \\
non biji yang diharapkan kurang \\
gesuai \\
4. Kualitas tampilan dan ukuran \\
buah semangka bulat non biji 1 \\
kurang seragam \\
5. Promosi buah gemangka bulat \\
non biji kurang baik
\end{tabular} \\
\hline $\begin{array}{l}\text { Opportunity }(0) \\
\text { 1. Buah semangka bulat non biji } \\
\text { banyak digemari masyarakat. } \\
\text { 2. Tempat membeli buah semangka } \\
\text { bulat non biji di Pasar } \\
\text { Tradisional } \\
\text { 3. Pangsa pasar buah semangka } \\
\text { bulat non biji luas } \\
\text { 4. Peranan dumia pendidikan } \\
\text { terhadan agribisnis buah } \\
\text { gemangka bulat nou biji tinggi } \\
\text { 5. Kesadaran masyarakat } \\
\text { mengkonsumsi buah semangka } \\
\text { bulat non biji tinggi }\end{array}$ & $\begin{array}{l}\text { Strategi (SO) } \\
\text { a. Meninglatkan kualitas } \\
\text { pengemasan buah semangka bulat } \\
\text { non biji yang menarik. } \\
\text { b. Meningkatkan distribusi buah } \\
\text { semangka bulat non biji } \\
\text { c. Meningkatkan produksi secara } \\
\text { kontinyu untuk memenuhi } \\
\text { permintaan buah semangka bulat } \\
\text { non biji. }\end{array}$ & $\begin{array}{l}\text { Strategi (WO) } \\
\text { 1. Meningkatkan keahlian petani } \\
\text { dalam agribisnis buah semangka } \\
\text { bulat non biji } \\
\text { 2. Meningkatkan kualitas promosi } \\
\text { buah semangka bulat non biji. }\end{array}$ \\
\hline 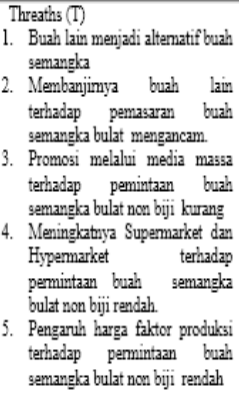 & 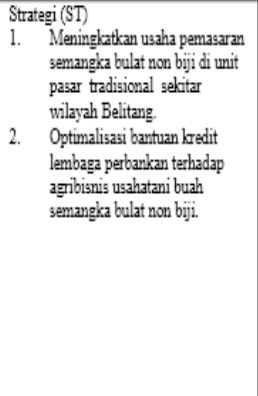 & $\begin{array}{l}\text { Strategi (WT) } \\
\text { 1. Meningkatkan peran altif para } \\
\text { pedagang untuk promosi buah } \\
\text { semangka bulat non biji } \\
\text { 2. Meningkatkan fekuensi } \\
\text { promosi buah semangka bulat } \\
\text { nom biji. }\end{array}$ \\
\hline
\end{tabular}

Sumber : Olahan Data Primer 2014.

\section{Strategi SO}

Strategi S-O (Strength-Opportunity) atau strategi kekuatan peluang adalah strategi yang menggunakan kekuatan internal untuk memanfaatkan peluang eksternal. Alternatif strategi S-O yang dapat dirumuskan adalah :

a. Meningkatkan kualitas pengemasan buah semangka bulat non biji yang menarik.

b. Meningkatkan distribusi buah semangka bulat non biji.

c. Meningkatkan produksi secara kontinyu untuk memenuhi permintaan buah semangka bulat non biji.

\section{Strategi ST}

Strategi S-T (Strength-Threat) atau strategi kekuatan-ancaman adalah strategi untuk mengoptimalkan kekuatan internal yang dimiliki dalam menghindari ancaman. Alternatif strategi S-T yang dapat dirumuskan adalah :

a. Meningkatkan usaha pemasaran semangka bulat non biji di unit pasar tradisional sekitar wilayah Belitang. b. Optimalisasi bantuan kredit lembaga perbankan terhadap agribisnis usahatani buah semangka bulat non biji.

\section{Strategi WO}

Strategi W-O (Weakness-Opportunity) atau strategi kelemahan peluang adalah strategi untuk meminimalkan kelemahan yang ada untuk memanfaatkan peluang eksternal. Alternatif strategi W-O yang dapat dirumuskan adalah :
a. Meningkatkan keahlian petani dalam agribisnis buah semangka bulat non biji
b. Meningkatkan kualitas promosi buah semangka bulat non biji.

\section{Strategi WT}

Strategi W-T (Weakness-Threat) atau strategi kelemahan-ancaman adalah strategi defensif untuk meminimalkan kelemahan internal dan menghindari ancaman eksternal. Alternatif strategi yang dapat dirumuskan adalah :

a. Meningkatkan peran aktif para pedagang untuk promosi buah semangka bulat non biji

b. Meningkatkan frekuensi promosi buah semangka bulat non biji.

Analisa yang membuat agar produk buah semangka bulat non biji dapat memberikan persepsi positif pada konsumen mengacu pada konsep 5 P (Poduct, Price, Place, Promotion, People) untukstrategi pemasaran buah semangka bulat non biji di Desa Triyoso Kecamatan Belitang.

\section{Produk (Hasil)}

Semangka bulat non biji di Desa Triyoso harus mempunyai ciri khas untuk memberikan kepuasan bagi konsumen buah semangka yaitu tekstur daging buah semangka padat, rasanya manis, biji buah semangka yang tidak terlalu banyak, ketahanan kulit buah semangka dapat mencapai 30 hari dari waktu panen dengan tekstur kulit buah yang tebal sehingga pada saat tumpuk buah semangka tidak mudah pecah.

2. Price (Harga)

Harga yang kita tawarkan harus terjangkau oleh konsumen sesuai dengan kualitas yang kita tawarkan. Bagi konsumen harga adalah suatu hal yang paling sensitif, semua orang menginginkan harga yang rendah dengan kualitas produk yang bagus. Harga buah semangka bulat non biji di Desa Triyoso terjangkau berdasarkan kelas buah semangka. 


\section{Place (Tempat)}

Bisnis kecil, menengah, maupun besar, permasalahan tempat tetap menjadi perhatian serius. Untuk membuka suatu usaha kita harus memilih tempat yang strategis, banyak dilalui orang, mudah dijangkau oleh kendaraan, menggunakan lokasi yang strategis dan mudah terjangkau seperti pasar di wilayah Kecamatan Belitang yaitu pasar Gumawang dan pasar Sidodadi merupakan wilayah terdekat dari Desa Triyoso sehingga petani sangat mudah dalam memasarkan buah semangka bulat non biji hasil usahataninya.

\section{Promotion (Promosi)}

Promosi harus tetap dilakukan oleh responden buah semangka bulat non biji Desa Triyoso Kecamatan Belitang gunanya adalah untuk menginformasikan secara terus menerus produk buah semangka bulat non biji kepada konsumen untuk membeli lagi produk buah semangka bulat non biji tersebut.

\section{People (Konsumen)}

Sebagai petani dan pedagang pada usahatani buah semangka bulat non biji harus membentuk jaringan dengan mebentuk asosiasi pedagang buah semangka atau konsumen akhir. Mulai dari teman atau media sosial untuk memperkenalkan produk buah semangka bulat non biji, tentunya hal ini dapat membantu mempromosikan produk buah semangka bulat non biji kepada asosiasi pedagang dan konsumen akhir, sehingga jaringan konsumen secara otomatis akan meluas.

\section{IV.KESIMPULAN DAN SARAN}

\section{A. Kesimpulan}

Berdasarnya hasil penelitian dan analisis yang telah dilakukan, maka dapat ditarik kesimpulan sebagai berikut:

1. Rata-rata hasil produksi semangka bulat non biji kelas A adalah 13.819, kelas B rata-rata produksinya adalah $2.210 \mathrm{~kg} /$ proses produksi, dan kelas $\mathrm{C}$ adalah sebanyak $558 \mathrm{~kg}$ dengan jumlah produksi keseluruhan sebesar 16.587 dan memberikan hasil penerimaan rata-rata sebesar Rp 60.538.064/proses produksi dikurang dengan rata-rata biaya produksi yang digunakan sebesar $\mathrm{Rp}$ 17.502.344/proses produksi memperoleh rata-rata pendapatan usahatani semangka bulat non biji sebesar Rp 43.035.720 /proses produksi.
2. Kondisi internal (kekuatan dan kelemahan) dan eksternal (peluang dan ancaman) sistem pemasaran semangka bulat non biji di Desa Triyoso Kecamatan Belitang adalah :

a.Kekuatannya adalah Pengembangan produksi hartikultura terutama untuk komoditi buah semangka mempunyai dampak yang sangat berarti terhadap pertumbuhan ekonomi Desa Triyoso. Produksi buah semangka bulat non biji mampu memenuhi kebutuhan masyarakat sejalan dengan meningkatnya permintaan dari konsumen Desa Triyoso maupun luar daerah desa Triyoso.

b. Kelemahannya adalah Petani sangat memerlukan pembinaan atau penyuluhan dari para penyuluh pertanian agar para petani mengetahui budidaya pengembangan semangka dan aplikasi praktiknya selain itu dapat memasarkan semangka dengan hasil yang tidak selalu merugikan sehingga dapat meningkatkan pendapatan petani dan Frekuensi promosi buah semangka kurang konsisten.

c. Peluangnya adalah buah semangka di Desa Triyoso tidak hanya dipasarkan di pasar tradisional saja, tetapi juga telah terbukti berhasil menembus pasar moderen misalnya supermarket. Hal ini membuktikan bahwa buah lokal memiliki keunggulan yaitu pangsa pasar yang luas, realitas ini menggambarkan kondisi masyarakat banyak yang menyukai, daya beli masyarakat mampu untuk membeli dan yang terpenting adalah bisa dirasakan oleh semua lapisan masyarakat.

d. Kelemahannya adalah peranan asosiasi produsen atau pemasar buah terhadap agribisnis buah semangka kurang baik. Kondisi agribisnis buah semangka saat ini yang masih jauh dari harapan, dapat dilihat dari lemahnya peran aktif asosiasi produsen atau pemasar buah semangka dalam perkembangannya.

3. Alternatif strategi yang dapat dikembangkan dalam pemasaran buah semangka bulat non biji di Desa Triyoso Kecamatan Belitang adalah : Mempertahankan kualitas produk benih dan meningkatkan kerja sama dengan stakeholder serta mempererat kemitraan untuk mempertahankan kontinuitas produksi dan dapat bertahan di pasaran, melakukan 
pengawasan terhadap resiko pemasaran buah semangka dengan pemerintah, Peningkatan pengelolaan usahatani semangka bulat non biji melalui kerjasama dengan instansi yang terkait dalam rangka menambah daya saing dalam pemasaran buah semangka. Memanfaatkan penyuluhan dan pelatihan dari PPL untuk meningkatkan kemampuan penguasaan teknologi, pengaksesan pasar dan pengelolaan keuangan yang baik. Mempertahankan dan meningkatkan kualitas produk benih dan menciptakan alternatif sarana produksi yang murah dan ramah lingkungan, Pengelolaan SDA dan limbah secara maksimal dengan pemerintah dan masyarakat Meningkatkan kualitas sumber daya petani secara teknis, moral dan spiritual untuk memaksimalkan produksi dan daya saing usahatani semangka. Menjalin kerja sama dengan masyarakat sekitar dalam rangka menjaga keharmonisan dan menambah kesempatan kerja.

\section{B. Saran}

1. Petani buah semangka agar lebih banyak menjual buah semangka kepada pedagang di pasar sekitar wilayah Belitang, karena dari segi harga lebih tinggi sehingga dapat meningkatkan pendapatan petani.

2. Petani buah semangka agar lebih memperhatikan waktu penanaman yang optimal yaitu pada musim kemarau agar hasil produksi dapat meningkat dan berkualitas, dan memilih varietas yang bagus sehingga hasil produksinya menjadi tinggi.

3. Mendasarkan pada potensi buah semangka di Desa Triyoso Kecamatan Belitang beserta analisis SWOT maka diperlukan suatu gerakan bersama meningkatkan agribisnis buah semangkal. Kegiatan ini harus dilakukan bersama mulai dari petani, lembaga pemasaran dan keperpihakan pemerintah.

\section{DAFTAR PUSTAKA}

Anonim. 2010. Ikhtisar Kandungan Gizi Semangka. Eemooesprit.blogspot.com. Diakses 20 Febuari 2014.

Assauri. 2002. Menejemen Pemasaran. PT.Raja Gravindo persada .jakarta.

Dinas Ketahanan Pangan Holtikultura Kecamatan Belitang OKU Timur 2009-2011.
Djamin. 1992. perencanaan dan anlisa proyek. Fakultas Ekonomi Universitas Indonesia. Jakarta.

Dimyati. 2007, Jaringan Pemasaran, http://www.citrusindo.org. Diakses 10 Januari 2014.

Gitosudarmo. 2008. Manajemen pemasaran. BPFE-Yogyakarta.

Hadayani dan Wayan. 2009. Kontribusi pendapatan ibu rumah tangga pembuat makanan olahan terhadap pendapatan keluarga. Diakses 7 Januari 2014.

Kartasapoetra, 1988. Pengantar ekonomi produksi. Bina Angkasa. Jakarta.

Kompas, 2005, Transportasi Agribinis \& Efektivitas Saluran Pemasaran, Hortikultura, Jakarta.

Kompas, 2005, Petunjuk Pelaksanaan Teknis Pengembangan Buah-buahan Melalui Model GAP (Good Agriculture Practise), Dinas Pertanian Propinsi Jawa Timur.

Kompas, 2007, Maraknya Pasar Swalayan Di Indonesia Membuka Peluang Baru Bagi Pasar Tradisional dan Petani.

Kompas, 2007, Buah Lokal Tidak Kalah Dari Buah Impor, http: // www.kompas.com. Diakses 10 Januari 2014.

Kotler, P. 2005. Dasar-dasar pemasaran. Indeks. Jakarta.

Limbong dan Sitorus. 2005. Pengantar tataniaga pertanian. Jurusan ilmu-ilmu sosial ekonomi pertanian institut pertanian Bogor. Bogor

Mursid. M, 2006. Manajemen pemasaran. Bumi Angkasa. Jakarta.

Nurul. 2002. Strategi pemasaran. Jakarta.

Sjarkowi, F dan Sufri, M. 2004. Manajemen Agribisnis. Baldad Grafiti Pres. Palembang.

Rangkuti, F, 1997, Analisis Swot; Teknik Membedah Kasus Bisnis. Gramedia Pustaka Umum. Jakarta.

Rangkuti, F., 2006, Analisis SWOT Teknik Membedah Kasus Bisnis, PT. Gramedia Pustaka Utama, Jakarta.

Wawan, H. 2006, Peranan Perguruan Tinggi Dalam Pengembangan Mekanisasi Pertanian,http://mekanisasi.litbang.deptan. go.id.

Yudi, B. 2010. Sistem Agribisbis Terintegrasi Hulu-Hilir. Muara Indah. Bandung. 